ISSN 0258-7122

Bangladesh J. Agril. Res. 36(4): 723-732, December 2011

\title{
EFFECT OF EXTENSION CONTACT ON RICE PRODUCTIVITY IN SOME SELECTED SITES OF GAZIPUR DISTRICT
}

\author{
ABU ZAFAR MAHMUdUL HAQ ${ }^{1}$
}

\begin{abstract}
The impact of extension contact is examined with a view to evaluating the agriculture extension in Bangladesh. It is found that the impact of extension contact is stronger for the comparatively near villages to upazila headquarters. This effect is weaker for those villages, which are comparatively away from upazila headquarters. Evident shows that the influence of extension contact is strongly positive and significant in the upazila where people are mostly involved in agricultural works. The results show that the impact of extension contact, which is one of the basic tenet of agricultural extension, as found in the yield of rice in the whole survey area, is strongly positive and significant. Some determinants of extension contact are also examined. Findings revealed that education of farmers, size of farm families, number of earners of farm families, irrigation and villages which are nearer to the upazila headquarters are key determinants for a household participation in extension contact.
\end{abstract}

Keywords: Extension contact, farmer, rice yield.

\section{Introduction}

In order to raise farmers' income and production in developing countries, governments and international organizations have been aggressively promoting agricultural extension services in those countries. According to a review of tens of researches by Birkhaeuser and Evenson (1991), on the whole, the extension services have contributed to some extent to raising the amount of information and thus the productivity levels of farmers. In the late 70 s, an extension system involving 12000 workers was initiated under the denomination of "Training and Visit System" hereinafter referred to as T\&V system in Bangladesh (Illah et al. 1996; Reynar et a1.,1996). Yet, whether or not that program actually contributed among the farmers' productivity in terms of income or physical production and if yes, whether the benefits of the system are homogeneously distributed among the farmers have not been clarified enough. The Gazipur district is one among many average rice productivity areas of Bangladesh. It is necessary to increase the rice productivity of Gazipur district. It will support to reach the self sufficiency of rice productivity in Bangladesh. Haq et al. (2003) found that the extension contact has positive impact on the income of farmers of the Gazipur district. It is also depicted that large farmers, higher income of farmers, young farmers are some key factors to adopt extension contact. The study is recognized but unclear

\footnotetext{
${ }^{1}$ Assistant Professor, School of Business, City University, Banani, Dhaka 1213. Data were collected from author's Ph.D Program.
} 
due to smaller samples and fewer study sites, respectively. To remedy this situation, serious studies on the extension services and its determinants are necessary. Thus the current paper based on farmers in the central area of Bangladesh, has two major objectives: 1) to assess the benefits of agricultural extension services on the productivity of rice and 2) to determine the type of farmers who benefited from the extension services.

\section{Methodology}

\section{Sampling design}

The research area was Gazipur district which is an average agricultural productivity area. The selection of the study sites and sample respondents were done purposively. There were some salient features in the selection procedure. First one, the selected district includes some important infrastructures, such as BARI, BIM, and BSMRAU, etc. Second one, total numbers of selected villages were ten by taking two villages from five upazilas. Of the two villages in each upazila, one village is selected comparatively near to the upazila headquarters and the other one is selected comparatively away from the upazila headquarters. The selected comparatively nearer villages were namely, Samantapur (Sadar), Bagnahati (Sreepur), Dushya Narayanpur (Kapasia), Katalia (Kaliakoir) and Poinlanpur (Kaliganj). The selected villages which were comparatively away from the upazila headquarters, namely, Bara Bhabanipur (Sadar), Saitalia (Sreepur), Noyanagar (Kapasia), Poshim Chandpur (Kaliakoir), and Bhatgati (Kaliganj). Third one, the total households were more than one hundred in the selected villages (BBS, 1993). It was then decided to collect one hundred samples from each village. The total numbers of investigated farmers were one thousand (2 villages $x 5$ upazilas x 100 farmers) and multistage random sampling technique was followed. Primary data was collected using survey method and personal interviews were conducted through pre-tested questionnaires with a view to collecting data. The survey was administered with the help of staffs of BARI in 2002. Fourth one, each upazila has some characteristics: Sadar upazila is completely urban type; Sreepur, Kapasia, and Kaliganj upazilas are rural type and headquarters of these upazilas are the only urban areas while Kaliakoir upazila headquarter is the only urban area and Safipur is the other urban area of this upazila (BBS, 1993). This study can be comprehensive compared to many research works due to the above salient features which will explore the actual situation of agriculture extension either in Bangladesh or elsewhere from the grassroots levels.

\section{Conceptual framework}

Many of the previous researches used the productivity index representing the amount of production per unit of farm land, that is, the value added of production, which is found by deducting production costs from gross income. By 
using that index, it is possible to convert the specific quantities of products into given amounts of money to be added up; therefore, it represents a considerable analytical benefit. The method of settling the type of variables from which the index is determined, expected to be discussed.

As is commonly used in analyzing production function, chemical fertilizer, farm buildings, irrigation facilities, family and hired labours should be considered as important investment functions (Everson et a1., 2001; Owens et a1. 2003). Haq et al.(2003) considered crop income per unit of land as dependent variable and chemical fertilizer cost per unit of land, irrigation cost per unit of land, experience of farmers, farm area, number of times extension contact as independent variables. Therefore, it summarized the model, Ln crop income $=\mathrm{f}$ (In chemical fertilizer, In irrigation, In experience, In farm area, In labour, extension contact dummy, extension contact dummy $)_{2}$ ). Haq et al. (2004) interpreted total income as dependent variable, while age of farmers, years of schooling of farmers, family size, number of educated family members, number of earners of a farm family, rural institutions dummy, number of times extension contact, proportionate effect of flood to crop land, distance between crop land to market, homestead area, size of farm, irrigation cost, village dummy were taken as independent variables. The income function was solved by applying ordinary least squares. The above concepts provide to run an empirical model which is found in the ensuing section.

\section{Empirical model}

The model applied here is the input-output model. The heart of the input-output model is the concept of the production function [Y=f (Capital, Labour)] which helps us in understanding the role of important variables like capital and labour in determining the crop productivity. But only two factors have no reflection on the productivity of a major crop like rice. Therefore, based on related past studies and logical analysis, some important explanatory variables which are considered in this study namely age of the farm household head (Ag), number of family earners in the household (Fea), number of times extension contact received by the farmer for the sample crop season (Et), proportionate effect (\%) of flood to crop land (Fec), distance from farm land to market in miles (Mr), actual size of cultivated land in acre (Fs), per acre total cost of chemical fertilizer (Chem), per acre total labour cost (Lab), per acre total money spent for irrigation (Irr), village dummy (dummy) $=1$ if near village; otherwise $=0$ and upazila dummy (Udummy) i.e. Sadar upazila $=1$, otherwise $=0$.

The yield of rice (maund/acre) is the dependent variable in the present paper as it is the major food crop in the country. It includes boro rice because it is hardly affected by the natural disaster compared to other rice crops and it was cultivated by all sample farms. 
In the objective of this research, the most important variable is that of the activities of the agricultural extension services. In Bangladesh $\mathrm{T} \& \mathrm{~V}$ system, farmlands are divided into blocks and the $\mathrm{T} \& \mathrm{~V}$ workers target the representative farmers of the different blocks, who are referred to as "contact farmers" (Haq et a1, 2003). Although the $\mathrm{T} \& \mathrm{~V}$ workers can directly get in touch with ordinary farmers, they mainly train the contact farmers, who afterwards transmit the training results to the other farmers, in a progressive system (ibid). Considering this situation in Bangladesh, the current paper used the frequency of contacts on the basis of actual number of times contacted between ordinary farmers and T\&V workers or contact farmers. Note that the combination of T\&V workers and contact farmers is hereinafter referred to as "extension agents" (ibid). Most of the farmers of Bangladesh are either illiterate or unskilled. Thus with the knowledge derived from extension services through extension contact, farm operators may increase their production (Haq et al., 2003; Owens et al., 2003). Relevant importance of other selected variables can be found in related literatures (Haq et al., 2004; Everson et al., 2001; Begum et al., 1998). Except for the variables of contact frequency, proportional effect of flood to crop land, village dummy and upazila "dummy, all the variables have been evaluated with a logarithmic converter to avoid disparities of the figures (Haq et a1., 2003; Owens et a1., 2003). Data have been analyzed by correlation and regression analyses. The productivity expressed in terms of physical quantity is as follows for village level analysis: Ln Rice yield = f (LnAg, Ln Fea, LnFs, Et, Fec, LnMr, Ln Lab, LnIrr, LnChem, Vdummy). For the upazila level analysis, the above function is, Ln Rice yield= $\mathrm{f}$ ( LnAg, Ln Fea, LnFs, Et, Fec, LnMr, Ln Lab, Lnlrr, LnChem, Vdummy, Udummy).

\section{Results and Discussion}

\section{Correlation Analysis}

It is argued by some researchers that a correlation analysis is necessary to identify the degree of association between the dependent and selected independent variables in order to determine their expected signs prior to multivariate analysis (Evenson et al., 2001). A bivariate analysis is done and Table -1 demonstrates the possible signs of selected numerous factors which can affect on the yield of rice. 
Table-1 Correlation analysis.

\begin{tabular}{|l|l|l|l|l|l|l|l|l|l|l|l|l|l|}
\hline Variables & Rice & Ag & Fm & Fea & Et & Fs & Fec & Mr & Chem & Irr & Lab & Vdummy & Udummy \\
\hline Rice & 1 & $-.06^{* *}$ & -.01 & .03 & $.08^{* * *}$ & $-.37^{* * *}$ & $-.05^{* *}$ & $-0.9 * * *$ & $.50^{* * *}$ & $.45^{* * *}$ & $.21^{* * *}$ & $-.18^{* * *}$ & $-.07^{* *}$ \\
\hline Ag & $-.06^{* *}$ & 1 & & & & & & & & & & & \\
\hline Fm & -.01 & & 1 & & & & & & & & & & \\
\hline Fea & .03 & & & 1 & & & & & & & & & \\
\hline Et & $.08^{* * *}$ & & & & 1 & & & & & & & & \\
\hline Fs & $-.37^{* * *}$ & & & & & 1 & & & & & & & \\
\hline Fec & $-.05^{* *}$ & & & & & & 1 & & & & & & \\
\hline Mr & $-.09^{* * *}$ & & & & & & & 1 & & & & & \\
\hline Chem & $.50^{* * *}$ & & & & & & & & 1 & & & & \\
\hline Irr & $.45^{* * *}$ & & & & & & & & & 1 & & & \\
\hline Lab & $.21^{* * *}$ & & & & & & & & & & 1 & & \\
\hline Vdummy & $-.18^{* * *}$ & & & & & & & & & & & 1 & \\
\hline Udummy & $-.07^{* *}$ & & & & & & & & & & & & 1 \\
\hline
\end{tabular}

***, ${ }^{* *} \& *$ indicate $1 \%, 5 \% \& 10 \%$ level of significance. 
Table 2. Results by village levels.

\begin{tabular}{|c|c|c|c|c|c|c|c|c|c|c|c|c|c|}
\hline Variables & Samantapur & Bagnahati & \begin{tabular}{|l} 
Dushya \\
Narayanpur
\end{tabular} & Katalia & Poilanpur & \begin{tabular}{|l|} 
All \\
Near \\
Villages
\end{tabular} & $\begin{array}{l}\text { Bara } \\
\text { Bhabanipur }\end{array}$ & Saitalia & Noyanagar & \begin{tabular}{|l|} 
Poshirn \\
Chandpur
\end{tabular} & Bhatgati & \begin{tabular}{|l|} 
All Far \\
Villages
\end{tabular} & \begin{tabular}{|l|} 
All \\
Villages
\end{tabular} \\
\hline \multirow[t]{2}{*}{ Constant } & $* * *$ & & $* *$ & $* * *$ & * & *** & ** & & $* * *$ & & & *** & $* * *$ \\
\hline & 4.761 & .353 & 2.598 & 4.080 & 1.127 & 6.090 & 2.450 & .725 & 7.418 & .514 & 1.222 & 10.788 & 12.296 \\
\hline \multirow[t]{2}{*}{ LnAg } & .039 & -.003 & $-.222 * *$ & $-.164 * *$ & $-.100 *$ & $-.053^{*}$ & -.025 & .032 & -.055 & $.072 *$ & .024 & $-.053 *$ & $-.058 * *$ \\
\hline & \begin{tabular}{|l|}
.383 \\
\end{tabular} & \begin{tabular}{|l|}
-.043 \\
\end{tabular} & -2.919 & $\mid-2.194$ & $\mid-1.717$ & -1.601 & -.341 & .579 & -.740 & 1.054 & .233 & -1.540 & -2.416 \\
\hline LnFea & $\begin{array}{l}.123 * \\
1.243\end{array}$ & $\begin{array}{l}.055 \\
.930\end{array}$ & $\begin{array}{l}.128 * \\
1.588\end{array}$ & $\begin{array}{l}.150^{* *} \\
2.103\end{array}$ & \begin{tabular}{|l|}
$.200 * * *$ \\
3.505
\end{tabular} & $\begin{array}{l}.134 * * * \\
4.042\end{array}$ & $\begin{array}{l}.146^{* *} \\
2.085\end{array}$ & $\begin{array}{l}.111^{* *} \\
1.996\end{array}$ & $\begin{array}{l}.274 * * * \\
3.795\end{array}$ & $\begin{array}{l}.033 \\
.497\end{array}$ & $\begin{array}{l}.169 * \\
1.668\end{array}$ & $\begin{array}{l}.105 * * * \\
3.028\end{array}$ & $\begin{array}{l}.127^{* * * *} \\
5.312\end{array}$ \\
\hline LnFs & \begin{tabular}{|l}
$-.414^{* *}$ \\
-2.956
\end{tabular} & \begin{tabular}{|l}
$-.445^{* *}$ \\
-4.235
\end{tabular} & \begin{tabular}{|l}
$-.331^{* *}$ \\
-2.863
\end{tabular} & $\begin{array}{l}-.532 * * * \\
-5.627\end{array}$ & $\begin{array}{l}-.461 * * * \\
-4.817\end{array}$ & $\begin{array}{l}-.460 * * * \\
-10.152\end{array}$ & $\begin{array}{l}-.325 * * * \\
-3.316\end{array}$ & \begin{tabular}{|l|}
$-378 * * *$ \\
-5.844
\end{tabular} & \begin{tabular}{|l}
$-.694 * * *$ \\
-9.349
\end{tabular} & $\begin{array}{l}-.499 * * * \\
-5.660\end{array}$ & $\begin{array}{l}-.197^{*} \\
-1.396\end{array}$ & $\begin{array}{l}-.531^{* * *} \\
-12.313\end{array}$ & $\begin{array}{l}-.481^{* * * *} \\
-15.737\end{array}$ \\
\hline Et & \begin{tabular}{|l|}
$.184 * *$ \\
2.002
\end{tabular} & \begin{tabular}{|l|}
-.003 \\
-.0445
\end{tabular} & $\begin{array}{l}.142^{*} \\
1.869 \\
\end{array}$ & $\begin{array}{l}.170 * * \\
2.302 \\
\end{array}$ & \begin{tabular}{|l}
$.067 *$ \\
1.221
\end{tabular} & \begin{tabular}{|l|}
$.116^{* * * *}$ \\
3.466
\end{tabular} & $\begin{array}{l}-.019 \\
-.268\end{array}$ & $\begin{array}{l}-.055 \\
-.616\end{array}$ & $\begin{array}{l}-.037 \\
-.301\end{array}$ & $\begin{array}{l}-.094 * \\
-1.584\end{array}$ & \begin{tabular}{|l|}
$.163 * *$ \\
1.961 \\
\end{tabular} & \begin{tabular}{|l|}
$.064 * *$ \\
1.842
\end{tabular} & $\begin{array}{l}.095^{* * * *} \\
3.944\end{array}$ \\
\hline Fec & $\begin{array}{l}.206^{* *} \\
-2.239 \\
\end{array}$ & $\begin{array}{l}209^{* *} \\
2.358 \\
\end{array}$ & $\begin{array}{l}-337 * * * \\
-3.800\end{array}$ & $\begin{array}{l}-267^{* * *} \\
-3.193 \\
\end{array}$ & $\begin{array}{l}.042 \\
-.779 \\
\end{array}$ & \begin{tabular}{|l|}
$-.072^{* *}$ \\
-2.128 \\
\end{tabular} & $\begin{array}{l}-302 * * * \\
-4.091\end{array}$ & \begin{tabular}{|l|}
$.221 * *$ \\
2.176
\end{tabular} & \begin{tabular}{|l|}
-.074 \\
-.567 \\
\end{tabular} & $\begin{array}{l}-198 * * \\
-2.987\end{array}$ & $\begin{array}{l}-246 * * \\
-2.495\end{array}$ & $\begin{array}{l}-.063^{* *} \\
-1.761 \\
\end{array}$ & $\begin{array}{l}-.073 * * \\
-2.981\end{array}$ \\
\hline LnMr & \begin{tabular}{|l}
$-.325^{* *}$ \\
-3.251 \\
\end{tabular} & $\begin{array}{l}.122 * \\
1.723\end{array}$ & $\begin{array}{l}-.099^{*} \\
-1.183\end{array}$ & $\begin{array}{l}-.075 \\
-.991 \\
\end{array}$ & $\begin{array}{l}-.080^{*} \\
-1.408\end{array}$ & \begin{tabular}{|l}
$-119 * * *$ \\
-3.464
\end{tabular} & $\begin{array}{l}.063 \\
.877\end{array}$ & \begin{tabular}{|l|}
$-.098 *$ \\
-1.460 \\
\end{tabular} & $\begin{array}{l}-.202 * * \\
-2.227\end{array}$ & $\begin{array}{l}.158 * * \\
2.817 \\
\end{array}$ & \begin{tabular}{|l|}
$.297 * *$ \\
2.577
\end{tabular} & $\begin{array}{l}.127^{* * * *} \\
3.808\end{array}$ & $\begin{array}{l}-.022 \\
-.900\end{array}$ \\
\hline LnLab & $\begin{array}{l}-.146^{*} \\
-1.069 \\
\end{array}$ & $\begin{array}{l}.022 \\
.213 \\
\end{array}$ & $\begin{array}{l}.242^{*} \\
1.908\end{array}$ & $\begin{array}{l}.004 \\
.036 \\
\end{array}$ & $\begin{array}{l}-.058 \\
-.716 \\
\end{array}$ & $\begin{array}{l}-.026 \\
-.558 \\
\end{array}$ & $\begin{array}{l}.316^{* * * *} \\
3.041\end{array}$ & \begin{tabular}{|l|}
$-.448^{* * * *}$ \\
-7.743 \\
\end{tabular} & $\begin{array}{l}-.404 * * * \\
-5.060\end{array}$ & \begin{tabular}{|l}
$-176^{* *}$ \\
-2.328 \\
\end{tabular} & $\begin{array}{l}.167 * \\
1.045\end{array}$ & $\begin{array}{l}-252 * * * \\
-6.443\end{array}$ & $\begin{array}{l}-137 * * * \\
-4.680 \\
\end{array}$ \\
\hline LnIff & $\begin{array}{l}-.095 \\
-.967\end{array}$ & $\begin{array}{l}.079 * \\
1.265\end{array}$ & $\begin{array}{l}.073 \\
.933\end{array}$ & $\begin{array}{l}.179 * \\
1.675\end{array}$ & $\begin{array}{l}.265^{* * *} \\
4.714\end{array}$ & \begin{tabular}{|l|}
$302 * * *$ \\
8.100
\end{tabular} & $\begin{array}{l}.048 \\
.597\end{array}$ & $\begin{array}{l}.055^{*} \\
1.038\end{array}$ & $\begin{array}{l}.115^{*} \\
1.595\end{array}$ & $\begin{array}{l}.121^{*} \\
1.811\end{array}$ & $\begin{array}{l}.158^{*} \\
1.127\end{array}$ & $\begin{array}{l}.016 \\
.427\end{array}$ & $\begin{array}{l}.265^{* * * *} \\
10.246\end{array}$ \\
\hline LnChem & \begin{tabular}{|l|}
-.048 \\
-.397 \\
\end{tabular} & \begin{tabular}{|l|}
$.395^{* * * *}$ \\
5.114 \\
\end{tabular} & \begin{tabular}{|l|}
.051 \\
.515 \\
\end{tabular} & \begin{tabular}{|l|}
$.177^{*}$ \\
1.564 \\
\end{tabular} & \begin{tabular}{|l|}
$.422^{* * * *}$ \\
5.413 \\
\end{tabular} & \begin{tabular}{|l|}
$.221^{* * *}$ \\
5.492 \\
\end{tabular} & \begin{tabular}{|l|l}
$.184^{* *}$ \\
2.056 \\
\end{tabular} & \begin{tabular}{|l|}
$.619^{* * * *}$ \\
8.866 \\
\end{tabular} & $\begin{array}{l}-.035 \\
-.493 \\
\end{array}$ & \begin{tabular}{|l|l|}
$.444^{* * * *}$ \\
5.184 \\
\end{tabular} & \begin{tabular}{|l|}
.104 \\
.744 \\
\end{tabular} & \begin{tabular}{|l|}
$.361^{* * *}$ \\
8.562 \\
\end{tabular} & \begin{tabular}{|l}
$.247^{* * * *}$ \\
8.702 \\
\end{tabular} \\
\hline \multirow[t]{2}{*}{\begin{tabular}{|l|} 
Vdummy \\
\end{tabular}} & --- & -- & -- & --- & -- & -- & -- & -- & -- & -- & -- & -- & -.149 \\
\hline & & & & & & & & & & & & & -6.068 \\
\hline $\mathrm{AR}^{2}$ & $.239 * * *$ & $.690 * * *$ & $.499 * * *$ & $.569 * * *$ & $.735 * * *$ & $.514 * * *$ & $.560 * * *$ & $.753^{* * *}$ & $.538 * * *$ & $.710 * * *$ & $.569 * * *$ & $.512^{* * *}$ & $.509 * * *$ \\
\hline F & 4.449 & 25.519 & 11.955 & 15.227 & 31.266 & 59.179 & 14.996 & 34.500 & 13.818 & 27.090 & 10.393 & 54.834 & 100.233 \\
\hline $\mathrm{N}$ & 99 & 99 & 99 & 97 & 98 & 492 & 99 & 99 & 99 & 96 & 64 & 457 & 949 \\
\hline
\end{tabular}

The figures are standardized coefficients (Beta) Italics denotes computed t-values; ***, ** \&* indicate $1 \%, 5 \%$ \& $10 \%$ level of significance. 


\section{Regression results}

The estimated values of coefficients and related statistics of the multiple regression coefficients of villages and upazilas are presented in Table 2 and Table 3. The adjusted $\mathrm{R}^{2}$ values agree with similar studies which are understandable because of the numerous factors affecting the yield of rice. The F-values are significant at $1 \%$ level of significance which implies that the specifications of the models were reasonably accurate (Begum et al., 1998). The results of the functional analysis suggest that except for few variables, all the variables had a positive effect on rice yield in the sample farms.

Table 3. Regression results by upazila levels.

\begin{tabular}{|c|c|c|c|c|c|c|}
\hline Variables & $\begin{array}{c}\text { Sadar } \\
\text { upazila }\end{array}$ & $\begin{array}{l}\text { Sreepur } \\
\text { upazila }\end{array}$ & $\begin{array}{c}\text { Kapasia } \\
\text { upazila }\end{array}$ & $\begin{array}{c}\text { Kaliakoir } \\
\text { upazila }\end{array}$ & $\begin{array}{c}\text { Kaliganj } \\
\text { upazila }\end{array}$ & $\begin{array}{c}\text { All } \\
\text { upazilas }\end{array}$ \\
\hline \multirow[t]{2}{*}{ Constant } & $* * *$ & $* *$ & $* * *$ & $* * *$ & $*$ & $* * *$ \\
\hline & 6.218 & 2.824 & 5.863 & 5.515 & 1.474 & 12.504 \\
\hline \multirow[t]{2}{*}{ LnAg } & .042 & -.001 & $-.102 * *$ & $-.080 *$ & $-.102 * *$ & $-.060 * *$ \\
\hline & .853 & -.035 & -2.040 & -1.526 & -2.092 & -2.576 \\
\hline \multirow[t]{2}{*}{ LnFea } & $.101^{* *}$ & $.095 * *$ & $.198 * * *$ & $.111^{* *}$ & $.201^{* * *}$ & $.149 * * *$ \\
\hline & 2.087 & 2.408 & 3.894 & 2.125 & 4.008 & 6.376 \\
\hline \multirow[t]{2}{*}{ LnFs } & $-.315 * * *$ & $-.435 * * *$ & $-.489 * * *$ & $-.591 * * *$ & $-.303 * * *$ & $-.473 * * *$ \\
\hline & -4.745 & -8.617 & -8.125 & -9.157 & -4.042 & -16.476 \\
\hline \multirow[t]{2}{*}{ Et } & .027 & .012 & $.112 * *$ & .039 & $.076^{*}$ & $.068 * *$ \\
\hline & .575 & .234 & 2.107 & .763 & 1.595 & 2.833 \\
\hline \multirow[t]{2}{*}{ Fec } & $-.155^{* * *}$ & $.198 * * *$ & $-.112 * *$ & $-.248 * * *$ & $-.053 *$ & $-.068 * *$ \\
\hline & -3.208 & 3.460 & -1.910 & -4.532 & -1.100 & -2.777 \\
\hline \multirow[t]{2}{*}{ LnMr } & .013 & $.057 *$ & $-.095 *$ & .003 & .015 & $-.086 * * *$ \\
\hline & .200 & 1.008 & -1.702 & .052 & .317 & -3.517 \\
\hline \multirow[t]{2}{*}{ LnLab } & .005 & $-.235^{* * *}$ & $-.307 * * *$ & $-.141 * *$ & -.016 & $-.155^{* * *}$ \\
\hline & .071 & -5.052 & -4.853 & -2.094 & -.217 & -5.593 \\
\hline \multirow[t]{2}{*}{ LnIrr } & .055 & $.075^{* *}$ & $.092 * *$ & $.125^{* *}$ & $.274 * * *$ & $.235 * * *$ \\
\hline & .762 & 1.879 & 1.828 & 1.930 & 5.486 & 8.340 \\
\hline \multirow[t]{2}{*}{ LnChem } & $.086 *$ & $.475^{* * *}$ & $.354 * * *$ & $.281^{* * *}$ & $.448 * * *$ & $.269 * * *$ \\
\hline & 1.419 & 9.717 & 5.967 & 3.941 & 7.091 & 9.821 \\
\hline \multirow[t]{2}{*}{ Vdummy } & $-.670 * * *$ & $-.272 * * *$ & .031 & -.016 & $-.215^{* * *}$ & $-.164 * * *$ \\
\hline & -8.223 & -5.161 & .520 & -.322 & -4.274 & -6.687 \\
\hline \multirow[t]{2}{*}{ Udummy } & --- & --- & --- & --- & --- & -.007 \\
\hline & & & & & & -.288 \\
\hline $\mathrm{AR}^{2}$ & $.589 * * *$ & $.725 * * *$ & $.583 * * *$ & $.576 * * *$ & $.664 * * *$ & $.535 * * *$ \\
\hline $\mathrm{F}$ & 29.334 & 53.560 & 26.383 & 27.384 & 33.196 & 101.102 \\
\hline $\mathrm{N}$ & 198 & 198 & 198 & 193 & 162 & 949 \\
\hline
\end{tabular}

The figures are standardized coefficients (Beta). Italics denotes computed t-values.

***, ** \& * indicate $1 \%, 5 \%$ \& $10 \%$ level of significance.

The coefficient for contact nearer villages is particularly great (0.116), compared to the villages away from the upazila headquarters (0.064). The contact coefficient is stronger in Kapasia upazila (0.112) which is followed by Kaliganj 
upazila (0.076) and other upazilas. According to Owens et al. (2003), a frequency of one and two operations per year between extension agents and farmers generate a high contribution to yield. However, a frequency of three or more than three times per year showed no clear effects in his study. Compared with the results of Owens et al. (2003), the results of Haq et al. (2003) suggests that in Bangladesh, the higher number of contacts ( 3 contacts or more per year) between extension agents and farmers seem more effective. Haq et al. (2003) found that the coefficient for 3 contacts or more per year was 0.353 , while the coefficient for 1-2 contacts per year was 0.234 . The present analysis suggests that in Bangladesh, the higher number of contacts between extension agents and farmers seem more effective than in the case of comparatively near villages with minor exception. Conversely, no such clear effects are found in the comparatively far villages since their coefficients are not significant. Jan et al. (2008) also observed that the coefficient for contact is stronger in the well situated villages. Analysis by upazila levels imply that higher number of contacts is more effective in the case of rural type upazila where more than eighty percent people are also engaged in agricultural works. Kapasia is a rural type upazila where the involvement of people in agricultural works is 80.15 percent (BBS, 1993) and the effect of contact is stronger in Kapasia upazila. Despite some similarities of other upazilas with Kapasia upazila, no clear effects of extension contacts in other upazilas are found as their coefficients are either significant or insignificant. The

more higher number of contacts are plausible because the farmers who have more than three contacts could get case - by - case suitable guidance encouraging the application of fertilizers or prevention of insects and diseases etc. (Haq et al., 2003). Accordingly, it is possible to ascertain in the context of all villages as well upazilas that the contacts with extension agents contributed to improve agricultural production per unit of farmland.

\section{Relationship of the selected characteristics of the farmers with their extension contact}

Since the average number of times for extension contact in the investigated areas was not higher, it is necessary to examine what type of farmers is provideding extension contact. Table 4 shows that extension contact is associated with the young age farmers, small size of farms, higher number of earners of a family, higher number of family members, little distance between farm land and nearest market, irrigation expenditures and comparatively near villages from upazila headquarters. The Vdummy is not important for extension contact. The relationship of Chem is insignificantly negative and hence, it keeps importance for extension contact. The insignificantly positive Ed implies that extension has importance for literate and illiterate farmers. According to Huffman (1974) extension activities help farmers who did not acquire enough school education to improve their ability to adjust. Similarly, the literate farmers may not be excluded 
from extension contact unless the quality of education is life oriented and this situation prevails in Bangladesh and other developing countries. The difference in the educational background of the farmers keeps influence the effectiveness of extension services and thus magnify the economic gap between farmers in a vicious cycle (Haq et al., 2003). Therefore, extension contact is necessary to provide among all farmers regarding their educational background since extension is a type of education for all.

Table 4. Relationship of the selected characteristics of the farmers with their extension contact.

\begin{tabular}{|c|c|c|c|c|c|}
\hline $\begin{array}{c}\text { Dependent } \\
\text { variable }\end{array}$ & $\begin{array}{c}\text { Characteristics } \\
\text { of farmers }\end{array}$ & $\begin{array}{c}\text { Correlation } \\
\text { coefficient }\end{array}$ & $\begin{array}{c}\text { Calculated } \\
\text { values }\end{array}$ & $\begin{array}{c}\text { Tabulated } \\
\text { values* }\end{array}$ & $\begin{array}{c}\text { Significance } \\
\text { level }\end{array}$ \\
\hline \multirow{10}{*}{ Et } & $\mathrm{Ag}$ & -0.012 & 0.704 & 0.254 & 0.01 \\
\hline & $\mathrm{Ed}^{3}$ & 0.047 & 0.142 & 0.164 & ns \\
\hline & Fs & -0.125 & 0.000 & 0.254 & 0.01 \\
\hline & Fea & 0.025 & 0.445 & 0.254 & 0.05 \\
\hline & $\mathrm{Fm}^{4}$ & 0.029 & 0.372 & 0.254 & 0.05 \\
\hline & $\mathrm{Mr}$ & -0.038 & 0.242 & 0.195 & 0.05 \\
\hline & Chem & -0.047 & 0.142 & 0.164 & ns \\
\hline & Irr & 0.133 & 0.000 & 0.254 & 0.01 \\
\hline & Vdummy & 0.104 & 0.001 & 0.254 & 0.01 \\
\hline & Udummy & -0.088 & 0.006 & 0.254 & 0.01 \\
\hline
\end{tabular}

*Bio Statistics: B K Mahajan, $6^{\text {th }}$ ed. Jaypee Brothers, India.

\section{Conclusion}

This paper was aimed at clarifying the effects of agricultural extension on improving the productivity of farmers with the example of one district of Bangladesh, emphasizing the relevance of number of times of extension contacts between farmers and extension agents. The results of the study can be summarized as follows:

First, from the estimated production function, it is clarified that the more the extension contacts between extension agents and farmers, the higher the productivity is. This clarifies that the extension contact has positive and significant effects in improving farm productivity. The effect of extension contact is stronger in those villages, which are nearer to upazila headquarters. The effect of extension contact is weaker in those villages which are comparatively away from upazila

* Note: ${ }^{3}$ Ed-Schooling years of the farm household head (Mean value is 5.77 years);

4 Fm-Number of family members of a household (Mean value is 5.34); Explanations of Et, Ag, Fs, Fea, Mr, Chem, Irr, Vdummy, and Udummy variables are same as previous sections. 
headquarters. The effect of extension contact is stronger in those upazilas where the involvement of people in agricultural works is about eighty percent.

Second, by examining the factors determining the contacts between extension agents and farmers, a positive correlation was found with the level of education, size of farm families, number of earners of farm families, irrigation, and villages which are nearer to the upazila headquarters. On the other hand, the size of farm, age of the farm household head, chemical fertilizer, distance between farm land to nearest market and upazila dummy variables have no direct relationship with the extension agents.

Considering the overall estimation, it has been possible to ascertain that agricultural extension positively contribute to increasing the rice productivity of farmers to some extent, but there is a necessity to develop the system toward more efficiency for all farmers in Gazipur district of Bangladesh. It is anticipated that the findings of the study will help the planners and policymakers of Bangladesh to offer a better agriculture extension in future.

\section{References}

Begum, R. 1998. An Economic Study of Wheat Production and Marketing in Bangladesh. Diss. Ehime University, Japan.

BBS.1993. Bangladesh Bureau of Statistics. In Bangladesh Population Census 1991. Zila:Gazipur, Ministry of Planning, GOB.

Birkhaeuser, D.and R.E.Evenson. 1991. The economic Impact of agricultural extension: A review. Econ. Dev. and Cul. Chan. 39(1):607-650.

Evenson, R. and G. Mwabu. 2001. The effect of agricultural extension on farm yields in Kenya. African Dev. Rev. 13(1):1-23.

Haq, A.Z.M., K. Taniguchi and A. Ishida. 2004. The impact of farmers' education on Income in Bangladesh. J. Japanese Soci. Agril. Tech. Mg. 11(1): 13-21.

Haq, A. Z. M., A. Ishida, S. Yokoyama and K. Taniguchi. 2003. Outcomes and issues of agricultural extension services in Bangladesh. J. Agril. Ext. Res. Japan. 8(17): 17-22.

Huffman, W. E. 1974. Decision making: The role of education. American J. Agril. Econ. 56(1):85-97.

Illah, S. M., A. K. Sarifullah and K. Ahsan. 1996. A comparative study on model farmer and training and visit systems of agricultural extension in Bangladesh. J. Res. Dev. BARD. 26(2):1-32.

Jan, I. N. Khan and S.N. Shaukat. 2008. Econometric analysis of the determinants of participation in agricultural extension services: An example from. Pakistan. $J$ Ext. Sys. 24(1): 63-75.

Mahajan, B. K. 1997. Bio Statistics: $6^{\text {th }}$ ed. Jaypee Brothers, India.

Ownes, T., Hoddinott and B.Kinsey. 2003. The impact of agricultural extension on farm Production in Resettlement areas of Zimbabwe. Econ. Dev. and Cul. Chan. 51(2): 337-357.

Reynar, R. and T.Bruening. 1996. Agricultural Extension Issues: Perception of Bangladesh T\&V Extension Personnel. J. Int. Agril. and Ext. Edu. 3(1):53-62. 